\title{
Parkinson's disease and wearable devices, new perspectives for a public health issue: an integrative literature review
}

\author{
Bruno Bastos Godoi $\mathbf{1}$ \\ (D) Gabriel Donato Amorim ${ }^{2}$ \\ Daniel Gonçalves Quiroga ${ }^{3}$ \\ Danessa Milanesi Holanda ${ }^{4}$ \\ (iD) Thiago Júlio ${ }^{5}$ \\ Marcelo Benedet Tournier ${ }^{6}$
}

\begin{abstract}
1. Universidade Federal dos Vales do Jequitinhonha e Mucuri; Diamantina, MG, Brasil 2. Escola Superior de Ciências da Santa Casa de Misericórdia de Vitória, Vitória, ES. Brasil 3. Universidade Federal de Mato Grosso, Cuiabá, MT, Brasil 4. Centro de Neurologia e Neurocirurgia Associados (NeuroCenna), BP - A Beneficência Portuguesa de São Paulo, São Paulo, SP, Brasil 5. Dasa - Diagnósticos da América, Barueri, SP, Brasil 6. Hult International Business School. Campus \& Enrollment Office. Hult International Business School, Cambridge, MA, USA.
\end{abstract}

http://dx.doi.org/10.1590/1806-9282.65.11.1413

\section{SUMMARY}

Parkinson's disease is the second most common neurodegenerative disease, with an estimated prevalence of 41/100,000 individuals affected aged between 40 and 49 years old and 1,900/100,000 aged 80 and over. Based on the essentiality of ascertaining which wearable devices have clinical literary evidence and with the purpose of analyzing the information revealed by such technologies, we conducted this scientific article of integrative review. It is an integrative review, whose main objective is to carry out a summary of the state of the art of wearable devices used in patients with Parkinson's disease. After the review, we retrieved 8 papers. Of the selected articles, only 3 were not systematic reviews; one was a series of cases and two prospective longitudinal studies. These technologies have a very rich field of application; however, research is still necessary to make such evaluations reliable and crucial to the well-being of these patients.

KEYWORDS: Parkinson's Disease. Wearable Electronic Devices. Technology. Review. Public Health.

\section{INTRODUCTION}

Parkinson's disease (PD) is a progressive neurodegenerative disease and characterized mainly by three typical motor symptoms: bradykinesia, muscle rigidity, and resting tremors ${ }^{1}$. PD is the second most common neurodegenerative disease, with an estimated prevalence of 41 cases for every 100,000 individuals aged between 40 and 49 years and 1,900 cases for every 100,000 individuals aged 80 years or more. According to these calculations, respecting the differences of the populations studied, the diagnostic criteria and methods used, by 2030, there will be about 9 million people with $\mathrm{PD}^{2}$.

Given this scenario, the therapeutic management of patients has been one of the main challenges, mainly due to the lack of instruments to properly measure the therapeutic response to the treatment instituted and the motor signs displayed by the patient in their daily lives ${ }^{3}$. 
In this context, the implementation of smart technologies for PD applications has increased in recent years. In particular, wearable sensors, which are a fundamental aid for early diagnosis, differential diagnosis, and in the objective quantification of symptoms in outpatients ${ }^{4}$. The use of wearable technologies to measure daily data is an important tool that is currently viable to obtain frequent parameters for patient assessment, mainly because they demonstrate the reality of the individual's behavior outside of the clinical environment, which differs from the examination normally done in clinics.

Thus, there is an increasing demand for new and better technologies that are useful and clinically validated for the treatment or monitoring of diseases, PD included, even more so due its complexity and heterogeneity, which implies the need of clinical assessment and appropriate management, with constant analysis of symptoms, fluctuations, and observation of worsening of symptoms and progression of the disease ${ }^{3,5-9}$. Currently, PD diagnosis is based on the assessment of motor and non-motor symptoms, as well as a neurological assessment. However, the diagnostic methods and approaches for monitoring disease progression disease remain below the ideal for the management of $\mathrm{PD}^{10}$, with failures or gaps that can and should be improved. For example, although highly relevant for PD, the use of clinical scales such as the Unified Parkinson's DiseaseRating(UPDRS), is restrictive, since it depends on the patient's status at the moment of the evaluation (there may be, for example, an assessment bias in patients who have the ON/OFF phenomenon on motor symptoms), it is limited by subjectivity and the clinical experience of the professional assessing the patient. Wearable devices, therefore, overcame many of these limitations by objectively quantifying results that are clinically relevant so that the test variations are reduced by their use $\mathrm{e}^{9,11,12}$. The measurement of motor symptoms by wearable devices is, in general, accurate and comparable to more established methods, with some of its aspects already tested and validated. The criteria evaluated refers to most of the motor symptoms (tremors, bradykinesia, dyskinesia) and have presented mostly moderate to high equivalence to standard clinical scales (for example, UPDRS, Modified Bradykinesia Rating Scale, among others) ${ }^{13}$.

Continuous long-term monitoring, therefore, has much more to offer in comparison to in-person clinical evaluations that may not reveal the true extent of symptoms ${ }^{14,15}$. Currently, such monitoring can be done from devices that utilize accelerometers, gyroscopes, magnetometers, and electromyography sensors, with possible uses such as the clinical observation of falls, tremors, bradykinesia, gait disorders, and mobility fluctuations ${ }^{15}$. The most appropriate way to measure the motor performance of patients seems to be the use of wearable devices based on inertial sensors, which can acquire data with a high sampling rate ${ }^{13,16-18}$. This has been developed for the assessment of several motor symptoms using a single or multiple systems. ${ }^{19,21,14,22-24}$

The main purpose of domestic monitoring is to provide optimal management of PD. Therefore, wearable devices with inertial sensors may represent an optimal solution for healthcare applications both in the clinical and domestic environment ${ }^{12}$. Under this perspective, the importance of wearable devices in the diagnosis ${ }^{25}$ and management of PD is clear ${ }^{9}$ since they can provide the physician with an understanding of the patient's scenario even in a simple evaluation?.

\section{METHODS}

This is an integrative review; according to Whitemore and Knalf ${ }^{26}$, the "term integrative originated from the integration of opinions, concepts, or ideas from research used in the method," which "highlights the potential to build science." Furthermore, an integrative review is a subtype of a systematic literature review, which can be subdivided into meta-analysis, systematic review, qualitative review, or integrative review.

Thus, in line with what is presented by Botelho et al. ${ }^{27}$ and Redeker ${ }^{28}$, this integrative review has the main objective of summarizing the state of the art of wearable devices used in PD patients. In addition, we also analyzed in which types of symptoms (motor or not) such technologies are used and if the data presented demonstrated superior monitoring by wearable devices in comparison with outpatient follow-up, or if these are complementary approaches.

The review consisted in searching the IEEEXplore, Lilacs, PubMed, SciELO, Arxiv, and ScienceDirectdatabases by using the following groups of descriptors (in accordance with the MeSH terms, DeCS, and Bireme): ("Monitoring, Ambulatory" OR "Wearable Electronic Devices" OR "Biosensing Techniques") AND "Parkinson Disease” AND “Motor Symptoms” AND ("Dis- 
TABLE 1. DESCRIPTORS USED ACCORDING TO THE PICO METHOD FOR SYSTEMATIC REVIEWS.

\begin{tabular}{l|l}
\hline Problem & $\begin{array}{l}\text { Parkinson Disease AND Parkinson Disease AND } \\
\text { Motor Symptoms }\end{array}$ \\
\hline Intervention & $\begin{array}{l}\text { Wearable Electronic Device OR Monitoring, } \\
\text { Ambulatory or Biosensing Techniques }\end{array}$ \\
\hline Comparison & - \\
\hline Outcome & $\begin{array}{l}\text { Disease Progression AND/OR Treatment Out- } \\
\text { come }\end{array}$ \\
\hline
\end{tabular}

ease Progression” OR “Treatment Outcome”). These were reviewed following the PICO method for systematic reviews (Table 1).

The inclusion criteria were: original articles, of meta-analysis, systematic, or integrative review, published between 2011 and 2018, peer-reviewed, in English, with data related to the use of wearable devices in the therapeutic management of symptoms of PD patients. The exclusion criteria were papers on subjects unrelated to the research topic, gray bibliography, duplicate references, articles on books, written in languages other than English. Also, references that did not include any type of wearable sensor (device). On that basis, we initially retrieved 24 papers (Graph 1), of which, after reading of the titles and abstracts and applying the inclusion and exclusion criteria, seven remained for evaluation in their entirety. After that, we excluded one paper, which was a systematic review of all types of technologies in the bradykinesia evaluation of Parkinson's patients. However, it did not specifically evaluate the wearable devices. In addition, the references of the articles retrieved were evaluated manually in order to select other studies that had not been included during the database search. We added one more paper, a sys- tematic review (Table 2), with a total of eight papers included in this review.

\section{RESULTS}

After the review, we found eight articles, which are listed in Table 2 with some of the conclusions by the authors of this paper after analyzing the data presented. Considering the data presented in Table 2 , we noted a scarcity of articles whose objective is to demonstrate the longitudinal follow-up of PD patients through the use of wearable devices.

Out of the eight articles selected, only three were not systematic reviews; one was case series and two prospective longitudinal studies. Patel et al. ${ }^{29}$ demonstrated in their study that by using a device called Mercurylive they could remotely assess two aspects of the UPDRS scale (Unified Parkinson's Disease Rating Scale), which is used mainly in the clinical environment, with the presence of the patient, to check, in particular, motor symptoms. The aspects evaluated in this study, as well as by the other two (Tzallas et al. ${ }^{24}$; Pastorino et al. ${ }^{21}$ ) are related to bradykinesia or daily motor fluctuations (ON/OFF phenomenon) (Figure 1). Considering that, in order to estimate the UPDRS scale, Patel et al. ${ }^{29}$ showed that a longitudinal follow-up with evaluations in three days had an error of 0.4 points in relation to the clinical evaluation performed by a trained professional.

Tzallas et al. ${ }^{24}$ used the Perform system (a prospective longitudinal study), which comprises three subsystems: a wearable device, a local-based unit, and a unit located at the hospital. With that, they

GRAPH 1. LIST OF THE NUMBER OF PAPERS FOUND IN THE RESPECTIVE DATABASES, WITH THE DESCRIPTORS USED.

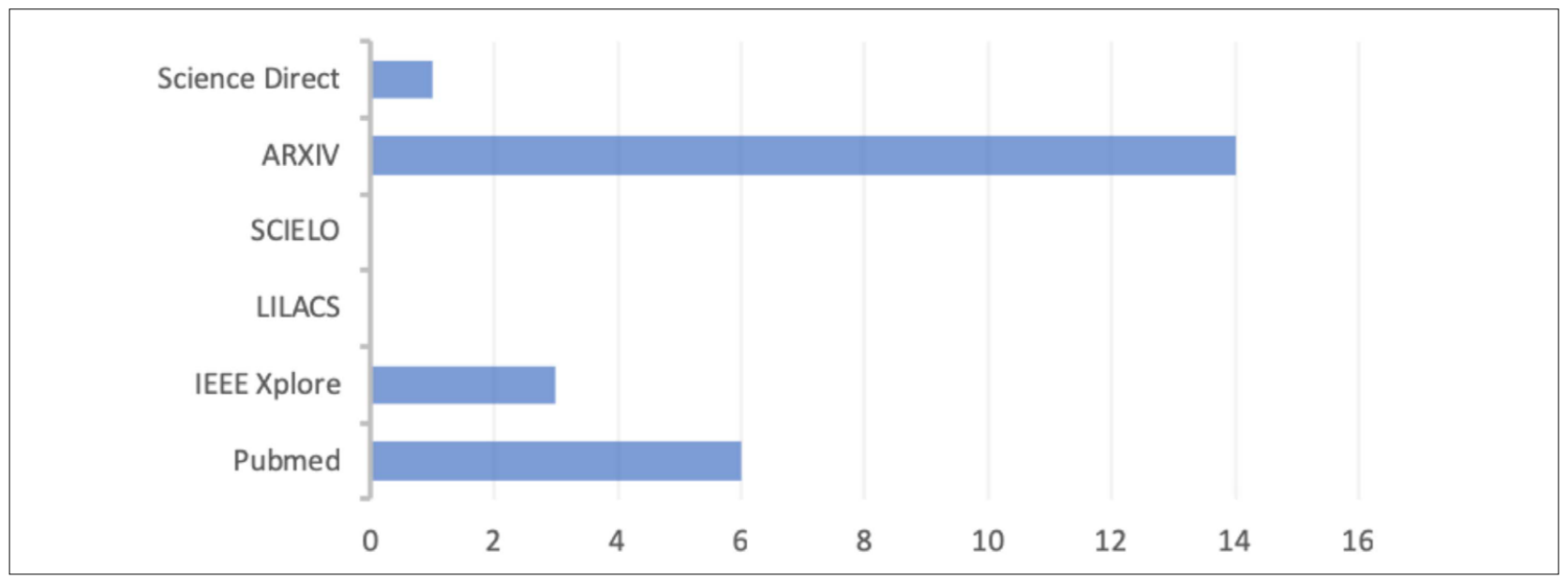


TABLE 2. LIST OF THE PAPERS SELECTED, THEIR GOALS, AND CONCLUSIONS.

\begin{tabular}{|c|c|c|c|c|}
\hline Authors/year & Title of article & $\begin{array}{l}\text { Type of } \\
\text { study }\end{array}$ & Study object & Study summary \\
\hline $\begin{array}{l}\text { Patel et al. }{ }^{29} \text {, } \\
2011\end{array}$ & $\begin{array}{l}\text { "Longitudinal } \\
\text { Monitoring of } \\
\text { Patients with } \\
\text { Parkinson's Dis- } \\
\text { ease via wearable } \\
\text { sensor technol- } \\
\text { ogy in the home } \\
\text { setting" }\end{array}$ & $\begin{array}{l}\text { Prospective } \\
\text { longitudinal } \\
\text { study }\end{array}$ & $\begin{array}{l}\text { Estimate the UPDRS score, by means } \\
\text { of wearable devices (Mercurylive, de- } \\
\text { veloped by the authors), which will eval- } \\
\text { uate two aspects: stomping heel first } \\
\text { on the floor repeatedly and alternating } \\
\text { pronation and supination of both hands. }\end{array}$ & $\begin{array}{l}\text { The authors concluded that it is possible to evaluate } \\
\text { the UPDRS score in its integrity using wearable de- } \\
\text { vices with an acceptable range of error. However, it } \\
\text { is still a challenge to develop this type of technology } \\
\text { that can be applied in the home of patients; it would } \\
\text { be necessary to have techniques to deal with the } \\
\text { uncontrolled environment of patients' homes. }\end{array}$ \\
\hline $\begin{array}{l}\text { Son et al. }{ }^{30} \text {, } \\
2018\end{array}$ & $\begin{array}{l}\text { "Mobility moni- } \\
\text { toring using smart } \\
\text { technologies for } \\
\text { Parkinson's dis- } \\
\text { ease in free-living } \\
\text { environment" }\end{array}$ & $\begin{array}{l}\text { Systematic } \\
\text { review }\end{array}$ & $\begin{array}{l}\text { Gather and review studies that tested } \\
\text { the feasibility of technology (wearable } \\
\text { devices) for non-ambulatory continu- } \\
\text { ous monitoring of PD patients. }\end{array}$ & $\begin{array}{l}\text { There are several wearable devices (WD) with } \\
\text { different goals, such as to evaluate motor symptoms } \\
\text { and their fluctuations or provide instant feedback } \\
\text { (both positive and negative) to the patient about } \\
\text { their posture. However, despite this myriad of WDs } \\
\text { and the problems associated with its adoption } \\
\text { and acceptance, they proved to be effective as an } \\
\text { adjuvant factor to the therapeutic process of PD } \\
\text { patients. }\end{array}$ \\
\hline $\begin{array}{l}\text { Pastorino et } \\
\text { al. }{ }^{\mathbf{2 1}}, 2013\end{array}$ & $\begin{array}{l}\text { "Preliminar results } \\
\text { os ON/OFF } \\
\text { detection using an } \\
\text { integrated system } \\
\text { for Parkinson's } \\
\text { disease monitor- } \\
\text { ing" }\end{array}$ & Case series & $\begin{array}{l}\text { Assess the motor fluctuations through- } \\
\text { out the day of PD patients (ON/OFF } \\
\text { effects) by means of wearable devices. } \\
\text { Such assessments are carried out in } \\
\text { patients' homes (uncontrolled environ- } \\
\text { ment) and later compared with data } \\
\text { collected from diaries kept by patients } \\
\text { based on motor symptoms throughout } \\
\text { the day. }\end{array}$ & $\begin{array}{l}\text { It is concluded that wearable devices are a great tool } \\
\text { to assess PD patients (particularly motor symptoms } \\
\text { and their daily fluctuations) remotely so that the } \\
\text { doctor can adjust doses or change medications. In } \\
\text { addition, it is associated with a low cost for patients } \\
\text { with chronic diseases. However, there is a need for } \\
\text { greater accuracy of wearable devices so that they } \\
\text { can be used indiscriminately. }\end{array}$ \\
\hline $\begin{array}{l}\text { Tzallas et al. }{ }^{24} \text {, } \\
2014\end{array}$ & $\begin{array}{l}\text { "PERFORM: } \\
\text { a system for } \\
\text { monitoring, } \\
\text { assessment and } \\
\text { management of } \\
\text { patients with Par- } \\
\text { kinson's disease" }\end{array}$ & $\begin{array}{l}\text { Prospective } \\
\text { longitudinal } \\
\text { study }\end{array}$ & $\begin{array}{l}\text { Describe the technological system for } \\
\text { remote management and monitoring of } \\
\text { PD patients regarding their: character- } \\
\text { istics; features compared to other sys- } \\
\text { tems; assessment of motor symptoms } \\
\text { in PD patients; analyses and aid in the } \\
\text { management of the disease. }\end{array}$ & $\begin{array}{l}\text { The management and treatment of PD are difficult } \\
\text { challenges since the treatment is different and } \\
\text { individualized, and management requires the active } \\
\text { participation of the patient for an assessment of the } \\
\text { daily routine and feedback. It shows the types of } \\
\text { analysis of the signs and symptoms by the system, } \\
\text { in addition to pointing out that, with the Perform } \\
\text { system, the health professional can have a remote, } \\
\text { precise and efficient assessment of the state of the } \\
\text { patient by means of gyroscopes and accelerometers, } \\
\text { and the continuous analysis of motor symptoms, } \\
\text { both quantitatively and qualitatively outside the } \\
\text { hospital environment, especially regarding clinical } \\
\text { information on medication response. }\end{array}$ \\
\hline $\begin{array}{l}\text { Ossig et al. }{ }^{31} \\
2016\end{array}$ & $\begin{array}{l}\text { "Wearable sen- } \\
\text { sor-based objec- } \\
\text { tive assessment of } \\
\text { motor symptoms } \\
\text { in Parkinson's } \\
\text { disease" }\end{array}$ & $\begin{array}{l}\text { Systematic } \\
\text { review }\end{array}$ & $\begin{array}{l}\text { Evaluate relevant data obtained by } \\
\text { wearable devices based on sensors } \\
\text { for assessing motor symptoms in PD } \\
\text { patients. The research focused on } \\
\text { systems based on accelerometers and/ } \\
\text { or gyroscopes. }\end{array}$ & $\begin{array}{l}\text { It is concluded that although it has been shown } \\
\text { that some devices or technologies are useful to dis- } \\
\text { tinguish between patients with or without PD and } \\
\text { provide access to quantified methods of continuous } \\
\text { monitoring, the feasibility of data obtained from } \\
\text { devices based on wearable sensors remains unclear } \\
\text { as a defining tool for trials and to improve routine } \\
\text { clinical care of PD patients. }\end{array}$ \\
\hline $\begin{array}{l}\text { Del Din et al. }{ }^{9} \text {, } \\
2016\end{array}$ & $\begin{array}{l}\text { "Free-living } \\
\text { monitoring of } \\
\text { Parkinson's dis- } \\
\text { ease: lessons from } \\
\text { the field" }\end{array}$ & $\begin{array}{l}\text { Systematic } \\
\text { review }\end{array}$ & $\begin{array}{l}\text { Generally analyze the current state of } \\
\text { the use of wearable devices by patients } \\
\text { outside the clinical environment and } \\
\text { describe the benefits and disadvan- } \\
\text { tages, future developments, evidence } \\
\text { and usefulness, and main challenges } \\
\text { of passive patient evaluation devices } \\
\text { regarding PD, in the precise detection } \\
\text { and measurement of clinical data. }\end{array}$ & $\begin{array}{l}\text { The advantages of the use of wearable devices in } \\
\text { PD have reached a stage in which they surpass eval- } \\
\text { uations that require attention and concentration, } \\
\text { in addition to scales (although important) that are } \\
\text { subjective and dependent on the patient. Therefore, } \\
\text { devices can quantify relevant clinical results and } \\
\text { response to treatment, thus reducing variations in } \\
\text { assessments and improving patient engagement } \\
\text { in the treatment. In general, technologies are a } \\
\text { necessity and promising, but further studies and } \\
\text { development are still needed, along with a multi- } \\
\text { disciplinary approach of sectors, so that they can be } \\
\text { finally adopted clinically and broadly. }\end{array}$ \\
\hline $\begin{array}{l}\text { Godinho et } \\
\text { al. }^{32}, 2016\end{array}$ & $\begin{array}{l}\text { "A systematic } \\
\text { review of the } \\
\text { characteristics } \\
\text { and validity } \\
\text { of monitoring } \\
\text { Technologies to } \\
\text { assess Parkinson's } \\
\text { disease" }\end{array}$ & $\begin{array}{l}\text { Systematic } \\
\text { review }\end{array}$ & $\begin{array}{l}\text { Perform a systematic review to list, } \\
\text { compare, and classify technological } \\
\text { devices (wearable, not wearable, and } \\
\text { hybrids) used to evaluate the motor } \\
\text { symptoms of PD patients. }\end{array}$ & $\begin{array}{l}\text { It is concluded that there is a rise in the develop- } \\
\text { ment of technologies to evaluate PD patients (with } \\
\text { clinical evaluations or not and related to motor } \\
\text { symptoms or not). However, attention must be paid } \\
\text { to the clinical-measurement properties of these } \\
\text { devices. }\end{array}$ \\
\hline
\end{tabular}


found an accuracy of more than $80 \%$ to identify daily motor fluctuations (ON/OFF phenomenon), with an accuracy of $87.5 \%$ to identify resting tremors, $74.5 \%$ for bradykinesia, $79 \%$ for changes in gait, and $85.4 \%$ of accuracy for patients in the ON stage. The most significant error was of 0.79 in the identification of changes in gait.

Pastorino et al. ${ }^{21}$, in a case series, assessed, for two consecutive days, the ON/OFF phenomenon by comparing the evaluation of wearable device with a self-assessment by the patient performed every 30 minutes, with three possible answers: OFF, ON with dyskinesia, and ON without with dyskinesia. We obtained an accuracy of $93.7 \%$ using the wearable device to identify motor fluctuations, compared with the self-assessment. They was also evaluated the comfort of using the technology, and $16 \%$ did not consider the device comfortable.

The other studies selected (Son et al. ${ }^{30}$; Ossig et al. ${ }^{31}$; Del Din et al. ${ }^{9}$; Godinho et al. ${ }^{32}$ ) are systematic reviews that compiled studies, still incipient, about the use of wearable devices in PD patients.

\section{DISCUSSION}

Wearable devices mark the beginning of a new era in medical assistance, taking medicine to unimaginable new places and providing more precise and efficient diagnostics and treatments ${ }^{33}$. In addition, the space occupied by this type of technology in modern medicine is evident. PD is a nosological entity that can be remotely evaluated by means of wearable devices ${ }^{9,21,24,29-32,34}$, which can be defined as technologies that can be, literally, worn by the patient without interfering in activities of daily life or the progression of the disease. That is, they can be watches or sensors that send data to centrals (which may be located in the assistant physician clinic), for future evaluation of the evolution of the clinical condition $^{35-40}$ (Figure 2). There are several devices, still under development, which evaluate different aspects of PD patients to assess the progression of symptoms, motor or not, or even to estimate some clinical scales, such as the Unified Parkinson's Disease Rating Scale (UPDRS) ${ }^{21,30,34}$. The Perform study aimed to describe the technological system for remote management and monitoring of PD patients regarding their: characteristics; features compared to other systems; assessment of motor symptoms in PD patients; analyses, and aid in the management of the disease. ${ }^{24}$. It is of great value for clinicians who follow-up these patients if these wearable devices can assist in monitoring patients, either in the initial approach, in diagnosis, prognosis, or even during treatment. In addition, it is important to check if there is a relevance of these evaluations by means of technologies comparing them to the evaluation performed by physicians. Hasan et al. ${ }^{34}$ conducted a study to estimate the UPDRS scale through evaluations conducted by patients and devices, which were then compared against each other and subsequently compared with clinical evaluations carried out by neurologists. However, they concluded that the use of such technologies was not superior to clinical assessments, despite having minimal errors in estimating the scale value ${ }^{34}$. It is worth noting that the diagnosis of PD is eminently clinical ${ }^{41}$. Moreover, in most cases, the monitor-

FIGURE 1. DAILY MOTOR FLUCTUATIONS IN PATIENTS WITH PARKINSON'S DISEASE (ON/OFF PHENOMENON).

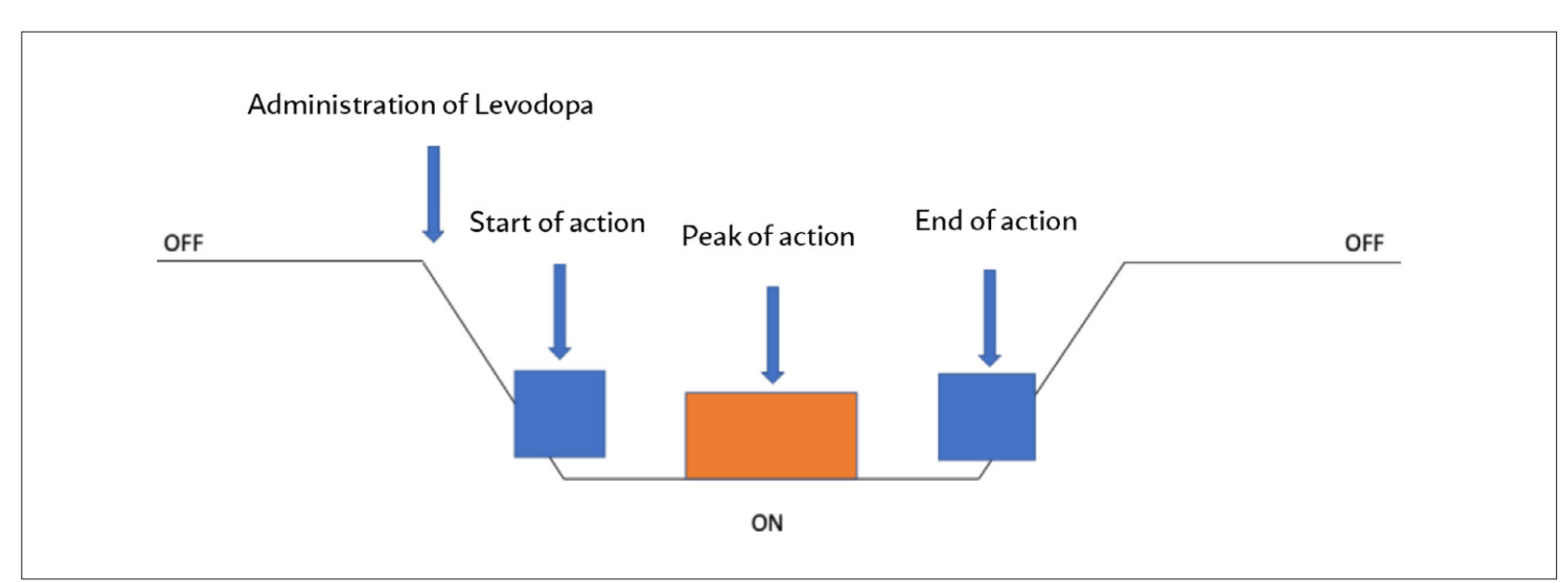


ing and treatment are also performed at outpatient clinics, except for patients who require deep brain stimulation $^{42}$. Thus, it becomes clear that the use of technologies must demonstrate superior data to those already well known from clinical assessments, using once again the UPDRS scale as an example, which is summarized in clinical parameters by which the physician evaluates the progression of the disease and, most importantly, the motor symptoms, as well as the ON/OFF phenomenon, very common in patients with $\mathrm{PD}^{21}$.

Studies have been developing wearable devices to evaluate and monitor patients with Parkinson's disease $^{9,21,24,29-32,34}$. However, after analyzing the scope of each of them, it is noted that most focus on the assessment of motor symptoms, which are already very well known. In addition, not all motor symptoms are assessed, most devices assess, basically, bradykinesia and, consequently, the development or not of the ON/OFF phenomenon. In addition, those that aim to estimate some clinical scale do so by means of a few aspects, in comparison with the various tests performed in outpatient evaluations. It is undeniable that with the knowledge of artificial intelligence and technology in medicine, some medical approaches have become obsolete. In the case of patients with Parkinson's Disease, wearable devices are able to carry out a full evaluation of the patient at times when it is not possible for a physician to do the same. Consequently, they can detect oscillations in symptoms that do not occur during an outpa- tient evaluation performed by neurologists or other trained professionals ${ }^{34}$.

However, studies that assess the use of wearable devices are still few and bring previous results and a small sample of patients, so they are not representative of the entire population of PD patients. In addition, these technologies were not superior to clinical assessments, even though they cannot identify symptoms fluctuations throughout the day. Thus, further studies are necessary to assess other aspects of PD, such as non-motor symptoms that predict the prognosis of patients. Attention should also be paid to the wearability of these devices, i.e., their comfort, and the cost they will generate for health systems or individuals with the disease. Therefore, it is evident the need for controlled and prospective that confirm their effectiveness, since there are still some points to be improved, such as the duration of batteries, diagnosis differentiation between other motor disorders, and predictive values for PD or other conditions in pre-motor stage or very early diagnosis, which are still considered "enigmatic"16,21.

Considering the above, in agreement with Rocha et al. ${ }^{43}$, wearable technologies used in PD must include the following features of any wearable device: monitoring, data transmission, analysis, diagnosis, and therapy, being able to minimize public health problems related to these patients.

The present study has some limitations; the technologies presented herein are restricted to those mentioned by scientific papers published

FIGURE 2. FIGURE ILLUSTRATING HOW WEARABLE DEVICES ARE USED FOR THE REMOTE MONITORING OF CLINICAL MANIFESTATIONS IN PATIENTS WITH PARKINSON'S DISEASE.

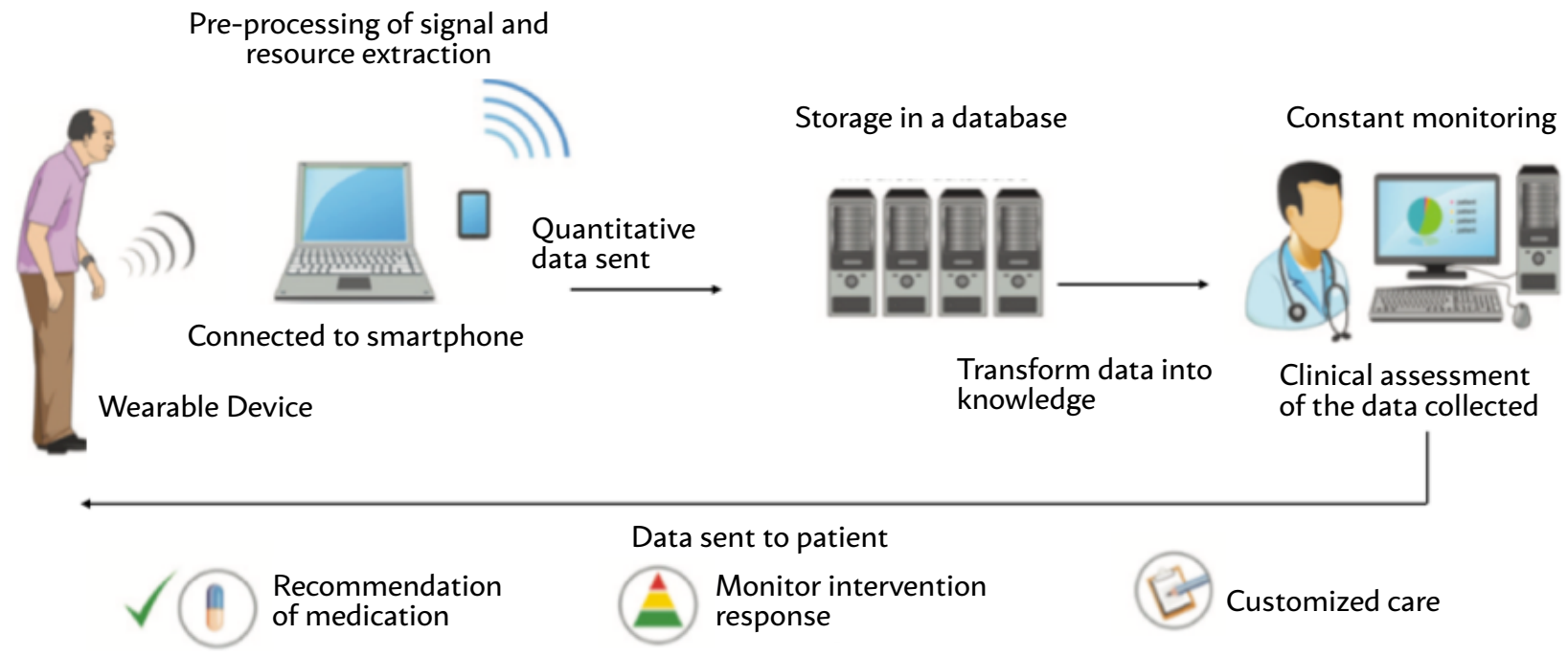


in indexed journals. However, there may be other technologies that are in use and feature more reliable parameters than those clinically assessed. In addition, other factors should be taken into account, such as the populations in which technology was applied, the stage of the disease, as well as adherence to the pharmacological treatment established by the physician. These parameters are of paramount importance in patient assessment and in the results obtained with such technologies. We should also remember that some technologies may be in development, considering the results presented by these studies in order to improve the assessment and monitoring of patients with Parkinson's Disease.

\section{CONCLUSION}

The use of wearable devices is becoming very important for the development of medical care. Several companies are investing in technologies that are able to check motor fluctuations, such as in PD, or even identify the heart rate and possible acute arrhyth- mias. Thus, such technologies become allies of doctors, aiding in the diagnosis of certain diseases or in the monitoring to evaluate how the patient adapts to the therapy established.

PD is characterized as a public health issue, especially among the elderly population, and can benefit from these wearable devices, whether it is to evaluate daily fluctuations of motor symptoms, such as the ON/OFF phenomenon, or to predict the results of clinical scales, such as the UPDRS.

However, there are still several barriers to overcome because the results presented are still scarce and do not demonstrate superiority to the evaluations performed on an outpatient basis by the physician. In addition, it is of utmost importance that the various aspects that make up the clinical condition of patients are assessed, such as the motor symptoms (already evaluated, but not in its entirety) and the non-motor as well, which have not been evaluated by any wearable device. In short, these technologies can have very broad applications, yet more research is still needed for these assessments to be reliable and crucial to the well-being of patients.

\section{RESUMO}

A doença de Parkinson figura como a segunda doença neurodegenerativa mais comum. Sua prevalência é estimada de 41 por 100.000 pessoas entre 40 e 49 anos a 1.900 por 100.000 pessoas com 80 anos ou mais. Baseando-se na essencialidade de averiguar os dispositivos vestíveis que possuem evidências clínicas literárias e com o objetivo de analisar as informações reveladas por tais tecnologias, temos a construção deste artigo científico de revisão integrativa. Trata-se de uma revisão integrativa que tem como principal objetivo realizar um sumário do estado da arte de dispositivos vestíveis utilizados em pacientes com doença de Parkinson. Após realizada a revisão, obtiveram-se oito artigos. Pode-se observar que dos artigos selecionados, apenas três não eram revisões sistemáticas, sendo um deles uma série de casos e outros dois, estudos longitudinais prospectivos. A utilização dessas tecnologias possui um campo muito rico para atuar, contudo ainda são necessárias pesquisas para que tais avaliações sejam fidedignas e cruciais para o bem-estar desses pacientes.

PALAVRAS-CHAVE: Doença de Parkinson. Dispositivos eletrônicos vestíveis. Tecnologia. Revisão. Saúde pública.

\section{REFERENCES}

1. Gelb DJ, Oliver E, Gilman S. Diagnostic criteria for Parkinson disease. Arch Neurol. 1999;56(1):33-9.

2. Pringsheim T, Jette N, Frolkis A, Steeves TD. The prevalence of Parkinson's disease: a systematic review and meta-analysis. Mov Disord. 2014;29(13):1583-90

3. Kassubek J. Diagnostic procedures during the course of Parkinson's disease. Basal Ganglia 2014;4:15-8.

4. Rovini E, Maremmani C, Cavallo F. How wearable sensors can support Parkinson's disease diagnosis and treatment: a systematic review. Front Neurosci. 2017;11:555.

5. Dickson JM, Grünewald RA. Somatic symptom progression in idiopathic Parkinson's disease. Parkinsonism Relat Disord. 2004;10(8):487-92.

6. Lau LM, Verbaan D, Marinus J, van Hilten JJ. Survival in Parkinson's disease. Relation with motor and non-motor features. Parkinsonism Relat Disord. 2014;20(6):613-6.

7. Caslake R, Taylor K, Scott N, Gordon J, Harris C, Wilde K, et al. Age-, gender-, and socioeconomic status-specific incidence of Parkinson's disease and parkinsonism in northeast Scotland: the PINE study. Parkinsonism Relat Disord. 2013;19(5):515-21.

8. Szewczyk-Krolikowski K, Tomlinson P, Nithi K, Wade-Martins R, Talbot $\mathrm{K}$, Ben-Shlomo Y, et al. The influence of age and gender on motor and non-motor features of early Parkinson's disease: initial findings from the Oxford Parkinson Disease Center (OPDC) discovery cohort. Parkinsonism Relat Disord. 2014;20(1):99-105.

9. Del Din S, Godfrey A, Mazzà C, Lord S, Rochester L. Free-living monitoring of Parkinson's disease: Lessons from the field. Mov Disord. 2016:31(9):1293-313.

10. Goetz CG, Tilley BC, Shaftman SR, Stebbins GT, Fahn S, Martinez-Martin P, et al; Movement Disorder Society UPDRS Revision Task Force. Movement Disorder Society-sponsored revision of the Unified Parkinson's Disease Rating Scale (MDS-UPDRS): scale presentation and clinimetric testing results. Mov Disord. 2008;23(15):2129-70.

11. Maetzler W, Rochester L. Body-worn sensors: the brave new world of clinical measurement? Mov Disord. 2015;30(9):1203-5. 
12. Papapetropoulos S, Mitsi G, Espay AJ. Digital health revolution: is it time for affordable remote monitoring for Parkinson's disease? Front Neurol. 2015;6:34.

13. Griffiths RI, Kotschet K, Arfon S, Xu ZM, Johnson W, Drago J, et al. Automated assessment of bradykinesia and dyskinesia in Parkinson's disease. Parkinsons Dis. 2012;2(1):47-55.

14. Espay AJ, Bonato P, Nahab FB, Maetzler W, Dean JM, Klucken J; Movement Disorders Society Task Force on Technology, et al. Technology in Parkinson's disease: challenges and opportunities. Mov Disord. 2016;31(9):1272-82.

15. Mellone S, Palmerini L, Cappello A, Chiari L. Hilbert-Huang-based tremor removal to assess postural properties from accelerometers. IEEE Trans Biomed Eng. 2011;58(6):1752-61

16. Palmerini L, Rocchi L, Mellone S, Valzania F, Chiari L. Feature selection for accelerometer-based posture analysis in Parkinson's disease. IEEE Trans Inf Technol Biomed. 2011;15(3):481-90

17. Cavallo F, Esposito D, Rovini E, Aquilano M, Carrozza MC, Dario P, et al. Preliminary evaluation of SensHand V1 in assessing motor skills performance in Parkinson disease. IEEE Int Conf Rehabil Robot. 2013;2013:6650466.

18. Sejdić E, Lowry KA, Bellanca J, Perera S, Redfern MS, Brach JS. Extraction of stride events from gait accelerometry during treadmill walking. IEEE | Transl Eng Health Med. 2016;4. pii: 2100111.

19. Horne MK, McGregor S, Bergquist F. An objective fluctuation score for Parkinson's disease. PLoS One. 2015;10(4):e0124522.

20. Mera TO, Heldman DA, Espay A|, Payne M, Giuffrida |P. Feasibility of homebased automated Parkinson's disease motor assessment. J Neurosci Methods. 2012;203(1):152-6.

21. Pastorino M, Cancela J, Arredondo MT, Pastor-Sanz L, Contardi S, Valzania F. Preliminary results of ON/OFF detection using an integrated system for Parkinson's disease monitoring. Conf Proc IEEE Eng Med Biol Soc. 2013;2013:941-4

22. Das $S$, Amoedo B, De la Torre F, Hodgins J. Detecting Parkinsons' symptoms in uncontrolled home environments: a multiple instance learning approach. Conf Proc IEEE Eng Med Biol Soc. 2012;2012:3688-91.

23. Ferreira ||, Godinho C, Santos AT, Domingos |, Abreu D, Lobo R, et al. Quantitative home-based assessment of Parkinson's symptoms: The SENSEPARK feasibility and usability study. BMC Neurol. 2015;15:89.

24. Tzallas AT, Tsipouras MG, Rigas G, Tsalikakis DG, Karvounis EC, Chondrogiorgi $M$, et al. PERFORM: a system for monitoring, assessment and management of patients with Parkinson's disease. Sensors (Basel). 2014;14(11):21329-57

25. Baali $H$, Djelouat $H$, Amira A, Bensaali F. Empowering technology enabled care using iot and smart devices: a review. IEEE Sens. J. 2017;18(5):1790-809.

26. Whittemore R, Knafl $K$. The integrative review: updated methodology. Advanced Nursing. 2005;52(5):546-53.
27. Botelho LLR, Cunha CCA, Macedo M. O método da revisão integrativa nos estudos organizacionais. Gestão e Soc. 2011;5(11):121-36.

28. Redeker NS. Sleep in acute care settings: an integrative review. J Nurs Scholarsh. 2000;32(1):31-8

29. Patel S, Chen BR, Mancinelli C, Paganoni S, Shih L, Welsh M, et al. Longitudinal monitoring of patients with Parkinson's disease via wearable sensor technology in the home setting. Conf Proc IEEE Eng Med Biol Soc. 2001;2011:1552-5.

30. Son H, Park WS, Kim H. Mobility monitoring using smart technologies for Parkinson's disease in free-living environment. Collegian. 2018;25(5):549-60.

31. Ossig C, Antonini A, Buhmann C, Classen J, Csoti I, Falkenburger B, et al. Wearable sensor-based objective assessment of motor symptoms in Parkinson's disease. J Neural Transm (Vienna). 2016;123(1):57-64.

32. Godinho C, Domingos |, Cunha G, Santos AT, Fernandes RM, Abreu D, et al. A systematic review of the characteristics and validity of monitoring technologies to assess Parkinson's disease. J Neuroeng Rehabil. 2016;13:24.

33. Chatterjee A, Gupta D. A study on the factors influencing the adoption: usage of wearable gadgets. $2^{\text {nd }}$ IEEE International Conference on Recent Trends in Electronics, Information \& Communication Technology (RTEICT) 2017;1632-5.

34. Hasan $H$, Athauda DS, Foltynie T, Noyce AJ. Technologies assessing limb bradykinesia in Parkinson's disease. J Parkinsons Dis. 2017;7(1):65-77.

35. Ometov A, Bezzateev SV, Kannisto J, Harju J, Andreev S, Koucheryavy Y. Facilitating the delegation of use for private devices in the era of the internet of wearable things. IEEE Internet Things |. 2017;4:843-54.

36. Liang $T$, Yuan Y). Wearable medical monitoring systems based on wireless networks: a review. IEEE Sens |. 2016;16(23):8186-99.

37. Pereira CR, Pereira DR, Weber SAT, Hook C, Albuquerque VHC, Papa JP. A survey on computer-assisted Parkinson's disease diagnosis. Artif Intell Med. 2019:95:48-63.

38. Tahir H, Tahir R, McDonald-Maier K. On the security of consumer wearable devices in the internet of things. PLoS One. 2018;13(4):e0195487.

39. In H, Abu-Raya YS, Haick H. Advanced materials for health monitoring with skin-based wearable devices. Adv Healthc Mater. 2017;6(11).

40. Hemapriya D, Viswanath P, Mithra VM, Nagalakshmi S, Umarani G. Wearable medical devices: design challenges and issues. 2017 Int. Conf. Innov. Green Energy Healthc. Technol. 1-6 (2017). doi:10.1109/IGEHT.2017.8094096

41. Beitz JM. Parkinson's disease: a review. Front Biosci (Schol Ed). 2014;6:65-74.

42. Okun MS. Deep-brain stimulation for Parkinson's disease. N Engl j Med. 2013;368(5):483-4.

43. Rocha TAH, Fachini LA, Thumé E, Silva NC, Barbosa ACQ, Carmo M, et al. Saúde móvel: novas perspectivas para a oferta de serviços em saúde. Epidemiol Serv Saúde. 2016;25(1):159-70. 